Integration of content instruction with constructivist-based strategies: An approach to teach first-year engineering mathematics

Choy, Jeanette Lyn Fung

Republic Polytechnic, Singapore (jnchoy@gmail.com)

Yeo, Wee Loon

Republic Polytechnic, Singapore (weelita179@gmail.com)

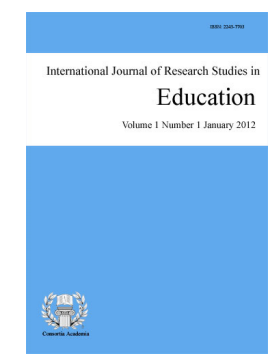

ISSN: $2243-7703$ Online ISSN: 2243-7711

OPEN ACCESS

\title{
Abstract
}

This paper proposed an approach to teaching first-year engineering mathematics, based on constructivist strategies, through careful integration of interactive lectures and small-group learning. Students' perceptions of learning mathematics through this approach were examined through both quantitative and qualitative approaches $(\mathrm{N}=425)$. The results from the student feedback scores indicated strong consensus among students that the integrated approach was useful in helping students gained knowledge and skills in solving mathematical problems (M $=3.85, \mathrm{SD}=.62$ ). Further insights gathered from the qualitative data revealed that students relished having more opportunities for practice under close guidance of the facilitator and resources. The discussion points to the appropriateness of using different teaching approaches to meet the diverse needs of learning of mathematics.

Keywords: mathematics education; constructivism; interactive seminars; small group learning 


\section{Integration of content instruction with constructivist-based strategies: An approach to teach first-year engineering mathematics}

\section{Introduction}

A scan of research literature examining ways mathematics education could be designed and delivered over the past decades revealed that the direct instruction approach had been increasingly complemented with approaches that are more aligned with the constructivist instructional approach. There is growing consensus among engineering and mathematics educators that it is essential for students to be actively engaged in order to learn successfully and develop diversified social skills needed in today's society (Bot, Gossiaux, Rauch, \& Tabiou, 2005; National Council of Teachers of Mathematics, 1989, 1991). This process is distinctly different from how mathematics has been taught traditionally where direct instruction is the commonly used approach of content delivery. Through this format, passive learners are receiving concepts explicitly from the educator. This would usually be reinforced by 'drills' where learners work on a variety of practice questions (Smith III, 1996). Conversely, constructivism is student-centred, learners are actively involved in a "continuous process of constructing and reconstructing his or her conceptions of phenomena" (Tynjälä, 1999, p. 364) with the teacher taking the role of a facilitator. In other words, a constructivist approach, as Cobb (1988) suggests, the goal for mathematics should go beyond acquiring mathematical knowledge through routinely prescribed methods such as merely solving mathematical tasks. To encourage this process to happen, the learning environment needs to entice students to stay engaged and design strategies that provide students with the opportunities to continually practice and test their understanding.

\subsection{Learning Mathematics in a Constructivist Learning Environment}

While there are advantages, challenges are present in the use of constructivist-based approach to teach mathematics. Such challenges arise due to the myriad of ways constructivist learning could be framed and applied in a learning context. For instance, various studies highlighted the association of constructivism with minimal guided discovery approach in the classroom setting (Kirschner, Sweller, \& Clark, 2006; Kroesbergen, Van Luit, \& Maas, 2004; Poncy, McCallum, \& Schmitt, 2010). Through this association, Krischner et al. (2006) described constructivist-based learning context as "learners, rather than being presented with essential information, must discover or construct essential information for themselves" (p. 1). Such an approach, they argued, was likely to be loosely structured and might not be productive for the delivery of lesson content that are computational in nature. Poncy et al. (2010) alluded to this in their study where they reported that 19 second-grade elementary students who received the constructivist-orientated intervention were not as skilled as compared to their peers who received behaviourist-based instruction when asked to perform subtraction-fact skill. In the experimental group, constructivist intervention was adopted whereby a series of questions was used to guide students inquiring process. Whereas students that experienced the behaviourist-based intervention with more direct instructions were required to learn by studying accurate models of solving a math fact. In the aspect of student motivation, they found that majority of the students (77\%) preferred the behaviourist approach. In another study, Kroesbergen et al. (2004) observed similar outcomes when they found that low-ability students performed better in basic multiplication tasks when their teachers explained and provided examples on how to solve the mathematical problems.

Furthermore, in the constructivist-based instructional approach, students are required to search for possible solution and construct their own mathematical knowledge. In this learning environment, teachers could guide students through asking questions and prompt them through further discussion. However, not all students seemed to have benefitted from this. This was demonstrated in a study by Baxter, Woodward and Olson (2001) where they observed that low achievers tend to be passive in group discussion and during learning activities. The 
authors noted that, conversely, average to high-ability students were more likely to participate actively and benefited from the constructivist-based instruction. The study concluded that low-ability learners lacked the ability to integrate new information with their prior knowledge and this inhibits subsequent construction of deeper understanding in learning mathematics.

In similar ways, students new to the constructivist learning environment, such as first-year students, are confronted with a qualitatively different pedagogy and therefore, lack appreciation of the learning ideology and practices or as Kirschner et al. (2006) termed 'schema' to thrive in the constructivist learning environment. For instance, instead of receiving information directly from teachers, students are now required to be actively engaged in self-directed learning as they process information, resources and instructional materials. Students also need to learn to utilise diverse social skills to adapt to different contexts and work with others (Savin-Baden, 2000).

Despite the divergent views on the use of constructivist-based approach for mathematics education, one common assertion remains - students need to receive adequate support and guidance from their teachers to be engaged in learning mathematics. The observation that low-ability learners lack schema to handle a constructivist learning environment is particularly important to the learning of mathematics as the subject is generally seen as a highly computational field where conceptual understanding of new knowledge builds on knowledge acquired earlier (Hart, 1980). Hence, students with existing difficulties in relating new information due to the lack of prior knowledge are likely to be further burdened while coming to terms with the constructivist-based approach and new learning activities such as problem-solving and collaborative work (Kirschner et al., 2006; Sweller, 1988). In view of these issues, there is a need to consider the integration of different approaches to help students learn mathematics.

\subsection{Learning Mathematics Through Different Approaches}

The amount of support and guidance needed varies for students of different abilities. In a class with students of diverse abilities and background, deliberate planning is essential especially in how support and guidance could be provided as they acquire mathematical concepts. The lack of adequate support and guided instructions could lead to poor learning of the subject (Sweller, 1988). Various scholars supported this view and illustrated how mathematics educators have innovated practices with the aim of engaging students and create more opportunities for students to deepen their understanding of mathematics. For example, many studies suggested adopting the 'multiple approaches' model where teachers used different approaches to enhance student engagement (Artigue \& Blomhøj, 2013; Even \& Kvatinsky, 2010). A common strategy employed to teach mathematics involved infusing interactive elements into traditional lectures and allocating students to smaller groups for collaborative learning. Other variations such as short lectures, small group activities and questioning exercises were found to help students develop a more conceptual understanding of mathematics. For example, Jaworski and Matthews (2011) described efforts to help first-year Materials Engineering students develop a more conceptual understanding of mathematics. In this case, techniques adopted included using inquiry-based questions designed to encourage exploration in mathematics, strategically incorporating a more reflective component into formal lectures and putting students into smaller groups for project work. Elsewhere, Borges, Goncalves, and Cunha (2003) advocated the partnership of lecturer and students during lectures to address problems such as low performance in mathematics and high dropout rates in the course offered. This initiative increased student engagement and interaction by eliciting them to ask questions, participate in discussion and craft solutions for real life problem. Effort such as these, as Van Dijk and Jochems (2002) commented, would enhance students' motivation in learning mathematics and resulted in significantly better academic results in the subject.

The use of interactive lectures and small group learning seek to address challenges in teaching mathematics to engineering students and to improve their class engagement. Scholars are noting the importance of mathematics and how it can provoke students to be effective problem solvers. There is a growing consensus 
among mathematics fraternity that problem solving is an essential activity that requires students to actively make sense of mathematical concepts. The use of scenarios carrying real-life problem has been strongly recommended by National Council of Teachers of Mathematics (NCTM) on teaching and learning in mathematics classes (NCTM, 1991). With an appropriate 'hook' (Goodnough \& Nolan, 2008) - problems which allow real-life application of knowledge concepts acquired - students were observed to be more motivated to learn and acquire better understanding (Dolmans, Wolfhagen, \& Ginns, 2010); consequently, improved the quality of learning (Woods, 1996). To construct understanding in mathematics, Hiebert et al. (1996) proposed that the subject needs to be made "problematic", whereby the concepts revolves around students solving of real-world problems. Ronis (2007) suggested that educators need to consider and emphasise the versatility of mathematics to real-world contexts and problems. In order to accomplish this, the teaching approach would need to be aligned to this purpose and help learners build towards this appreciation. This is echoed in Md Kamaruddin and Wan Ahmad's (2007) study which found that students were more likely to understand abstract concepts through concrete experiences. Compared to the conventional approach of learning mathematics, whereby their respondents described it as "mechanistic ... memorising the formula and solving problems using the formula" (Kamaruddin \& Wan Ahmad, 2007, p. 14), the same study also reported that students learned faster using contextualised problems and develop critical thinking skills during problem solving.

\subsection{Research Purpose}

The purpose of this study was to introduce an integrated approach to interactive lectures and conducting small groups learning to teaching first-year Engineering Mathematics using strategies designed to minimise the problems students faced in a constructivist learning environment. The new approach consisted of two learning segments: 1) involving students in a problem-solving process through assimilating them in an interactive lecturing environment (interactive seminars) for acquisition of new mathematical concepts and utilizing multiple resources to assist in the development of problem-solving techniques, and 2) working in smaller groups (small groups learning) for practicing and applying their newly acquired concepts to solve the real-life problem. In addition, this research also explored into student perceptions of learning mathematics through this approach via both quantitative and qualitative methods. Student views relating to various key features of this new approach in learning mathematics were reported. This paper proposed that inclusion of more interactive approaches and small group learning could enhance the learning experience of students in undertaking subjects that are computational in nature. Such initiatives could lead to greater student engagement and deeper levels of understanding.

\subsection{Context of the study}

The context of this discussion was set in 'Introduction to Engineering Mathematics', a mandatory 15 week module for all first-year engineering students at a post-secondary educational institution. The staff members from the School of Engineering module designed each lesson to consist of two sessions: 1) an interactive seminar, and 2) the collaborative learning session (CLS). Both sessions were scheduled to take place on the same day. Class size for each interactive seminar session was 50 students, whereas each of the CLS session consisted of a smaller group size of 25 students.

This integrated approach was chosen after much research and careful weighing of the strengths and constraints of direct instruction and constructivist approaches. The combination of instructional strategies was designed intentionally to optimise opportunities for independent and group learning. In addition, teachers could guide students more closely while they grappled with the lesson content with their peers and during self-practice. The strategies adopted for the interactive seminar and CLS sessions are described below.

Interactive Seminars - Each lesson commenced with a 2 hour interactive seminar in the morning. Students usually start the class with a short quiz. This quiz served an important function of prompting students to recall the content taught in the previous lesson as this would later help them to connect to new concepts taught in the 
lesson for that day. Ronis (2007) termed this intent as the 'Engagement' stage in the constructivist learning model. At this phase, the author elaborated, educators help students connect 'past and present learning experiences', 'lay the organizational groundwork for the activities ahead, and activate student involvement in these activities in anticipation of the learning activities' (p. 29). Other than contributing to the lesson grade, quiz results also gave the teacher feedback on learning gaps or misconceptions of students.

Following the quiz, the teacher introduced the problem context for the day. This problem context was based on real life scenarios they could encounter in their daily lives or future professional endeavours. For example, while considering the problem context of designing a roller coaster ride, students were introduced to quadratic equations. By anchoring the lesson to real world scenarios, students would learn deeper knowledge by participating in 'authentic practice'. According to Sawyer (2006), students engaged in authentic practice when they participated and situated their learning in practices that were central to their professional life in that discipline. By doing so, Cotton (2001) observed that students can be encouraged to apply or extend their understanding to realistic situations leading to higher levels of confident in their newly gained knowledge.

As indicated in the earlier section, the strength of the direct instructional approach lies in its effectiveness in mapping out 'strategic' or 'procedural' learning outcome (Askew, 2001). This quality was salient to the teacher, hence, its inclusion in the module. However, the teacher only taught the lesson in short segments of 10 to 15 minutes each. Building on the problem context, the teacher then mapped out the broad concepts and demonstrated the steps of calculation. With the completion of each step, practice questions were released to students for their practice. At this juncture, the educator was available for questions. Students could consult their friends but in limited capacity due to time constraint. A student could be nominated to demonstrate the steps of calculation on the white board. Any errors or doubts could be addressed by the educator before proceeding to the next step of calculation. These activities were recurring as the lesson increased in difficult and complexity.

During appropriate points of the lesson, the teacher would introduce useful resources to further scaffold student learning and increase interactivity. Resources ranged from newspaper articles, video clips to website. Other learning activities such as online polls or games would be inserted as appropriate. Careful planning prior to the lesson was essential as these resources were designed to support or challenge student thinking. Such a strategy is congruous to what Delaney (2001) comments as 'bringing the mathematics to the resources' (p. 124) because this provokes students to explore beyond their current awareness and engagement of the lesson.

Interactive seminars are useful in teaching core lesson objectives to a large group of students and at the same time, engaging through carefully planned learning activities. However, challenges persist. Educational literature put forward other considerations in how student learning can be enhanced. For example, the importance of collaborative learning (Shimazoe \& Aldrich, 2010), the benefits of reflection during learning (Sawyer, 2006) and finding ways to engage students with mixed abilities (Nelson, 1996). Van Dijk and Jochems (2002) noted these challenges and argued that learners were not likely to become active in this direct instruction approach. This is especially poignant for inexperienced learners or those with low self-efficacy. They suggested adopting a constructivist view of learning which involves student in the active construction and accumulation of knowledge rather than passive participation. This view that new information cannot be imparted as personally meaningful by the actions of a teacher alone stemmed from John Dewy's and Jean Piaget's idea of active learning. More educational researchers are echoing this view as evident in the current shift toward interactive approaches and small group learning.

Similarly, in the case of the 'Introduction to Engineering Mathematics, for students to gain further from the interactive seminars, further opportunities had to be created for students to be supported, explore, articulate and reflect on what they learnt, both individually and with their peers. Against this backdrop, the staff members organised compulsory small group learning classes for the students.

Collaborative Learning Sessions - After the interactive seminar, students were given a break before the collaborative learning session (CLS). During the CLS, the teacher usually starts the lesson with a short recap of 
what was covered in the earlier seminar before releasing a set of practice questions to the class. Given a smaller class size of 25 students, students have more opportunities to work on practice questions under the close guidance of the teacher. Students were encouraged to work through these questions as a group. Research indicates that collaborative learning, especially in small groups, can be beneficial to learning in the acquisition of both subject knowledge and tacit skills (Simpson, Hoyles, \& Noss, 2006). In their review of small group tutorials, Dolmans and Schmidt (2006) showed that small group study foster interactive learning and positive cognitive effects such as activation of prior knowledge, recall of information and knowledge construction. Yackel, Cobb, and Wood (1991) also reported the positive effects of small group learning on student motivation to learn and this was irrespective of students' ability. In a separate study, Shimazoe and Aldrich (2010) observed that low-ability students benefitted in heterogeneous ability groups while high-ability students developed deeper understanding by articulating the information to their peers. In view of these advantages, students of mixed abilities worked on the practice questions together in groups.

In addition to the practice questions, other learning activities were introduced to enhance their understanding. These activities involve students demonstrating their understanding in a variety of ways. For example, the teacher could task each group to come up with questions for their peers to work on and provide guidance to the whole class to devise the solution together. Such strategies stemmed from constructivist principles which call for the learner to externalise and articulate their developing knowledge (Sawyer, 2006). Furthermore, through articulation, learners were provided with the opportunities to reflect on their developing understanding and at the same time, think about their own process of learning.

After completing the learning activity, this process of articulation and reflection did not end as students were asked to connect what they have learnt to the real world problem context introduced at the start of the day by applying the steps of calculation to come up with a solution. Finally, the teacher would usually end the lesson with a final recap of the learning objectives and the solution of the problem.

\section{Methods}

In the context of this integrated approach of using interactive seminar and small-group collaborative learning session to support and guide student learning, feedback from students is crucial. Both quantitative and qualitative data were collected to explore student perspectives about learning mathematics through interactive seminar and collaborative learning session.

\subsection{Participants}

Participants in this study were first-year students enrolled in the 'Introduction to Engineering Mathematics' at a post-secondary institution. A total of 1149 students took the module for one semester, consisting 15 lessons per week. Surveys were administered to these students between Week 8 to Week 10 of the semester. Out of these 1149 students, 425 students (39\% female) participated in the survey. A focus group discussion for students was conducted on Week 12 of the semester. Based on consultation with the module head that oversees the module and consent from the students, 48 students of varying academic results were asked to participate in the discussion.

\subsection{Measures}

Module Feedback Survey - To obtain information on how students perceive learning mathematics in this new environment, a module feedback survey was designed. Administered by the institution at the 10th week of the semester, the module feedback survey is a formative tool to provide teachers with feedback on the module based on the students' perspectives. The design of the module feedback survey focus on the specific learning and teaching associated with the module, along with some indication of the problems of accessing module-specific learning resources. The survey consisted of 16 items on 3 indicators: (1) perceived value of learning (PVL, 4 items), (2) perceived quality of learning resources (PQL, 8 items), and (3) perceived appropriateness of 
integrated approach (PIA, 4 items). The items are chosen based on institution's need to measure the extent that students' perceived the module is of value to them (consisting of statements on how the module is interesting and of value to their future profession), the extent that students' perceived the module provide quality tasks and materials (consisting statements on how the learning resources and tasks has provided assistance to student learning), and the extent that students' perceived that the integrated approach is appropriate and helpful to them in learning the subject matter (consisting statements on how the overall structure of the learning approach were helpful to the students). These questions were scored on a 5-point Likert scale, ranging from 1 (strongly disagree) to 5 (strongly agree). Furthermore, the inquiry contained 2 open questions to provide students the opportunity to elaborate on what they enjoy most about the module and to suggest ways to improve it.

Focus Group Discussion - Four focus group discussions (FGD) with a maximum of 12 students each were conducted to acquire further insights on student perspectives learning via this integrated approach. Students of varying academic results were invited to participate in this session. FGDs were focused to obtain information on factors influencing student enjoyment and possible hindrances learning mathematics in the IL and CLS sessions. It further explored their views on how the learning process can be improved. Data obtained from the FGD was corroborated and assisted in clarifying points arising from the survey. Semi-structured method of interview was used. Each FGD lasted approximately for an hour and was recorded in note.

\section{Results}

\subsection{Quantitative results from module feedback survey}

Effectiveness of the integrated approach in delivering the mathematics module based on the student perspectives was examined by analysing students' responses to 16 statements relating to the perceived value of learning (PVL), perceived quality of learning resources (PQR) and perceived appropriateness of integrated approach (PIA). The responses were categorised in terms of students' level of agreement with the statements associated with each of the category based on a 5-point Likert scale ranging from Strongly Agree to Strongly Disagree (see Table 1).

Overall, the mean confidence across all items was $3.85(\mathrm{SD}=.62)$, indicating that students agreed that the integrated approach is useful in helping them learn mathematics. Based on 425 responses to the module feedback survey, the module was rated highly on most indicators. There were high frequencies (68\%) of students agreeing and strongly agreeing that they see value in the module, PVL, that the module was professionally useful (78\%) and interesting (71\%). Relatively lower frequencies (31\%) of students reported that they agreed and strongly agreed that the module provides quality learning resources (PQL). In examining the items further under PQL, it was reported that some of the students had difficulties relating the learning tasks to what they know (32\%) and some of them found that the learning resources were difficult to understand and apply (30\%). Nevertheless, most of the students rated highly on the learning tasks in engaging them in learning (79\%) and thinking (77\%). In addition, most of the students agreed that the learning resources were useful in helping them to complete the learning tasks (73\%). As for students' feedback for the interactive seminar approach to learning engineering mathematics, PIA, $65 \%$ of the students agree that this is an effective and appropriate approach for them in learning mathematics.

\subsection{Qualitative results from module feedback survey}

The student views presented in Table 1 provided student perspectives on the effectiveness of learning mathematics in this integrated approach from various angles. Their views on whether they enjoyed the teaching approaches were explored in the survey by asking two open questions: "What did you enjoy most about the module?" and "In what ways can the module be improved?" A total of 363 positive comments were made regarding what students enjoyed about the module, and 262 comments were offered suggesting ways to improve. These comments varied in depth and degrees of elaboration. The qualitative data was analysed to identify 
Choy, J. L. F., \& Yeo, W. L.

common recurring themes.

Table 1

Student feedback ratings for the module $(n=425)$

\begin{tabular}{|c|c|c|c|c|c|c|}
\hline Items & $\begin{array}{c}\text { Agree \& } \\
\text { Strongly } \\
\text { Agree }(\%)\end{array}$ & Neutral (\%) & $\begin{array}{c}\text { Disagree } \\
\& \text { Strongly } \\
\text { Disagree }(\%)\end{array}$ & $\begin{array}{l}\text { Mean } \\
\text { ratings }\end{array}$ & $\mathrm{SD}$ & $\begin{array}{l}\text { Cronbach's } \\
\text { alpha }\end{array}$ \\
\hline Perceived Value of Learning, PVL & $68 \%$ & $26 \%$ & $6 \%$ & 4.03 & .76 & .93 \\
\hline I enjoyed the module & $83 \%$ & $13 \%$ & $4 \%$ & 4.19 & .85 & \\
\hline I am clear about the learning objectives of this module & $84 \%$ & $13 \%$ & $3 \%$ & 4.15 & .81 & \\
\hline $\begin{array}{l}\text { I find that the module is relevant to the profession I am } \\
\text { being prepared for }\end{array}$ & $78 \%$ & $17 \%$ & $5 \%$ & 4.00 & .84 & \\
\hline I find the topics in this module interesting & $71 \%$ & $24 \%$ & $5 \%$ & 3.90 & .89 & \\
\hline Perceived Quality of Learning Resources, PQL & $31 \%$ & $64 \%$ & $5 \%$ & 3.70 & .57 & .82 \\
\hline The learning tasks enabled me to engage actively in learning & $79 \%$ & $17 \%$ & $4 \%$ & 4.00 & .80 & \\
\hline The learning tasks sufficiently triggered thinking & $77 \%$ & $19 \%$ & $4 \%$ & 3.97 & .80 & \\
\hline $\begin{array}{l}\text { I had difficulties relating the learning tasks to what I know } \\
\text { and understand* }\end{array}$ & $32 \%$ & $36 \%$ & $32 \%$ & 3.02 & 1.11 & \\
\hline $\begin{array}{l}\text { The learning tasks stimulated my interest to find out more on } \\
\text { my own }\end{array}$ & $71 \%$ & $25 \%$ & $4 \%$ & 3.88 & .85 & \\
\hline $\begin{array}{l}\text { The learning tasks helped me to relate the concepts taught to } \\
\text { real world issues and application }\end{array}$ & $67 \%$ & $26 \%$ & $7 \%$ & 3.80 & .89 & \\
\hline $\begin{array}{l}\text { The learning resources that were required for the seminar } \\
\text { and assignments were adequately available }\end{array}$ & $75 \%$ & $20 \%$ & $5 \%$ & 3.93 & .83 & \\
\hline $\begin{array}{l}\text { The learning resources helped me to address and complete } \\
\text { the learning tasks }\end{array}$ & $73 \%$ & $23 \%$ & $4 \%$ & 3.94 & .82 & \\
\hline $\begin{array}{l}\text { The learning resources were too difficult to understand, } \\
\text { apply or operate* }\end{array}$ & $30 \%$ & $36 \%$ & $34 \%$ & 3.07 & 1.11 & \\
\hline Perceived Appropriateness of Integrated Approach, PIA & $65 \%$ & $29 \%$ & $6 \%$ & 3.94 & .75 & .90 \\
\hline $\begin{array}{l}\text { The seminar/lesson materials were organised in ways that } \\
\text { were helpful for me to follow through the lesson }\end{array}$ & $75 \%$ & $21 \%$ & $4 \%$ & 3.94 & .82 & \\
\hline $\begin{array}{l}\text { The seminar/lesson materials were organised in ways that } \\
\text { were helpful for me to do my revision }\end{array}$ & $75 \%$ & $21 \%$ & $4 \%$ & 3.93 & .83 & \\
\hline $\begin{array}{l}\text { I feel that the learning have helped me gain more knowledge } \\
\text { and understanding about the profession and industry }\end{array}$ & $69 \%$ & $25 \%$ & $6 \%$ & 3.84 & .88 & \\
\hline $\begin{array}{l}\text { Overall, the module is conducted in an appropriate format } \\
\text { for learning the content }\end{array}$ & $78 \%$ & $17 \%$ & $5 \%$ & 4.04 & .91 & \\
\hline
\end{tabular}

Note. ${ }^{*}$ indicates item that is reverse coded

For questions 1 , the highest number of comments $(n=58)$ was how students enjoyed learning the new things through this format. They stated that this format was clear and made lessons easier to follow:

"I feel quite comfortable to ask questions and share my views in this fun and conducive learning environment."

They found learning fun and interesting which some attributed to the teacher's ability to engage the class $(\mathrm{n}=$ 18).

"It is helpful because we get to ask questions. The teacher is very encouraging and we get more attention."

Students also commented on how they enjoyed the opportunity of working and learning with classmates. Some explained that this format afforded ample opportunities for practice and clarifying doubts with each other or the teacher easily $(n=21)$. They appreciated the lesser time spent in school and the opportunity to end the day earlier.

\section{"I am given ample practice questions to practice on and revise further."}

"For people who can't catch up, the facilitator will come personally. Rest of the class continues with their work."

Students were asked to suggest areas of improvement in question 2. No clear trends could be drawn but five respondents commented on timing for both collaborative learning sessions. They suggested holding concurrent classes because the 2 hour break after interactive seminar was too long. Students $(n=3)$ found the practice 
Integration of content instruction with constructivist-based strategies: An approach to engineering mathematics questions and video useful and suggested including more of them in the worksheet.

\subsection{Results from focus group discussions}

To further examine factors that influence student views on why they enjoyed the integrated approach and possible hindrances learning mathematics in this environment, four FGD that consisted of 12 students in each group were conducted. The qualitative data was analysed and summarised into four main themes with their respective sub-themes based on what they enjoyed about the integrated approach (see Table 2) and the suggested areas for improvements (see Table 3).

\section{Table 2}

Student views on what they enjoyed about the integrated approach $(n=48)$

\begin{tabular}{|c|c|c|}
\hline Major themes & $\begin{array}{l}\text { Subthemes with representative } \\
\text { comments }\end{array}$ & Example of response \\
\hline \multirow[t]{3}{*}{$\begin{array}{l}\text { 1. Learning } \\
\text { environment }\end{array}$} & Opportunity to practice & $\begin{array}{l}\text { "I have more chance to practice. Maths is about } \\
\text { practicing." }\end{array}$ \\
\hline & Asking questions & $\begin{array}{l}\text { "I feel quite comfortable to ask questions and share } \\
\text { my views in this fun and conducive learning } \\
\text { environment" }\end{array}$ \\
\hline & Self-directed learning & $\begin{array}{l}\text { "Views of mathematics changed a bit... This allows } \\
\text { me to take more initiative in my own learning." }\end{array}$ \\
\hline 2. Resources & $\begin{array}{l}\text { Resources are useful in helping to } \\
\text { understand lesson }\end{array}$ & $\begin{array}{l}\text { "External resources, video, web links are useful." } \\
\text { "The videos attached at the beginning of each } \\
\text { sub-topic in the worksheet are very useful as they } \\
\text { contain all the important key concepts of the topic. I } \\
\text { could better understand some of the topics taught after } \\
\text { watching the videos." }\end{array}$ \\
\hline \multirow[t]{5}{*}{ 3. Engagement } & $\begin{array}{l}\text { Engagement through practice } \\
\text { questions }\end{array}$ & $\begin{array}{l}\text { "Integrated approach allowed more practice which is } \\
\text { useful." }\end{array}$ \\
\hline & Clear lesson structure & $\begin{array}{l}\text { "Learn to do maths step by step. Easier to follow even } \\
\text { if I am not good in maths." }\end{array}$ \\
\hline & $\begin{array}{l}\text { Teacher's feedback in class is } \\
\text { helpful }\end{array}$ & $\begin{array}{l}\text { "Very encouraging. My teacher is able to adjust the } \\
\text { pace to suit student learning." }\end{array}$ \\
\hline & & $\begin{array}{l}\text { "The feedback given to me is timely and useful as } \\
\text { they contain information that I can take note of, about } \\
\text { my class performance and what I can improve on." }\end{array}$ \\
\hline & Quiz as a source of feedback & $\begin{array}{l}\text { "Quiz is useful in helping me with the lesson. Motivate } \\
\text { me in doing the pre-reading." }\end{array}$ \\
\hline \multirow[t]{3}{*}{ 4. Learning } & Pace of lesson & $\begin{array}{l}\text { "The pace of the lesson is relatively easy to follow } \\
\text { unless if I don't have the background knowledge in } \\
\text { the topic(s) taught." }\end{array}$ \\
\hline & Practising calculations in learning & $\begin{array}{l}\text { "This method of learning had changed my attitude and } \\
\text { views of this module. Previously, I wasn't practising } \\
\text { much on Mathematics but after this method of } \\
\text { learning, I personally feel that in order to get good } \\
\text { grades in Maths, there must be practice and more } \\
\text { practice." }\end{array}$ \\
\hline & Prior knowledge & $\begin{array}{l}\text { "Learning more about the topic in a new and } \\
\text { interesting way. Progressive. Build on what I have } \\
\text { learnt in secondary school." }\end{array}$ \\
\hline
\end{tabular}

\section{Discussion}

In recent years, considerable attention has been paid to how mathematics could be best taught. While no consensus has been reached on one ideal approach, most researchers attributed the abstract nature of mathematics to the profusion of approaches and student responses. For many students, mathematics remains a series of challenges which they face with relish and confidence. While for many others, they experience 
Choy, J. L. F., \& Yeo, W. L.

continued failure and perceive mathematics as irrelevant. Hence, the consideration and discussion of how mathematical content could be effectively delivered to students of diverse needs, competencies and confidence levels should be of prime importance among educators in this field.

Table 3

Student suggestions on how the integrated approach can be improved $(n=48)$

\begin{tabular}{|c|c|c|}
\hline Major themes & $\begin{array}{l}\text { Subthemes with representative } \\
\text { comments }\end{array}$ & Example of response \\
\hline $\begin{array}{l}\text { 1. Learning } \\
\text { environment }\end{array}$ & $\begin{array}{l}\text { Managing class dynamics during } \\
\text { Interactive Seminar } \\
\text { Asking questions }\end{array}$ & $\begin{array}{l}\text { "Prefer to be with students from my own class, stick } \\
\text { with students with own. Other students are very noisy." } \\
\text { "I don't dare to ask questions during Interactive } \\
\text { Seminar as there were too many people." }\end{array}$ \\
\hline 2. Resources & $\begin{array}{l}\text { Tendency not to complete } \\
\text { pre-readings }\end{array}$ & $\begin{array}{l}\text { "Pre-reading materials are useful. Some students did } \\
\text { pre-reading. Majority not." }\end{array}$ \\
\hline 3. Engagement & $\begin{array}{l}\text { Stronger links to real life } \\
\text { applications }\end{array}$ & $\begin{array}{l}\text { "Not really relevant as the course that I'm currently } \\
\text { studying now is on Diploma in Industrial and Operations } \\
\text { Management which is a little more to the business and } \\
\text { operations side." }\end{array}$ \\
\hline \multirow[t]{2}{*}{ 4. Learning } & Easier to be distracted & $\begin{array}{l}\text { "Easier to be distracted as students' laptops are not } \\
\text { facing the teacher who is standing in front of the lecture } \\
\text { room." }\end{array}$ \\
\hline & $\begin{array}{l}\text { Content too simple for those with } \\
\text { advanced maths background }\end{array}$ & $\begin{array}{l}\text { "I feel that the pace was too slow because I have done } \\
\text { advanced mathematics subject in secondary school." }\end{array}$ \\
\hline
\end{tabular}

In order to gain insight on how students perceived interactive seminars and collaborative learning sessions, we examined and compared student responses from student feedback scores and focus group discussions. We found that students generally enjoyed the module and thought the format was useful in helping them progressively understand the steps involved in complex mathematical calculations. This point was reinforced during the focus group discussion where students elaborated that they relished having more opportunities for practice and benefitted from close guidance of their teachers. From their responses, the learning environment was crucial in facilitating collaborative learning and at the same time, afforded students the time to grapple with the concepts individually. Furthermore, students were comfortable in approaching the teaching staff to asking further questions. In particular, the provision of timely feedback is crtical to the success of this approach. This could be seen for the comments given by students where teacher's feedback in class is helpful, such as:

"The feedback given to me is timely and useful as they contain information that I can take note of ..."

All the above factors would have contributed high perceived value of learning score by students.

Lesson structure was another well-received feature of the integrated approach, especially for the interactive seminars. Students generally welcomed how the lesson content was systematically sequenced in the order of increasing complexity. Many commented that they could follow the lesson easily and relished having opportunities to consolidate their understanding at key junctures. The preference for structure in their learning is evident in the positive views garnered in the quality of the resources and how it was utilised during the interactive seminars as well as CLS. Students revealed in the focus group discussions that they felt the resources were introduced at the right junctures and complemented the learning activities well. They also commented that these resources gave the lesson more variety and led to greater levels of understanding. As such, despite difficulties relating to learning tasks and resources as revealed from the module feedback survey, students were able to manage their learning through the manner that the Interactive Seminar is being designed. Some students reflected that the interactive seminars helped them to recall and build on mathematical concepts learnt previously. This suggests that students were able to make some connections to their prior knowledge. In addition, students appreciated the inclusion of a real world context as it allowed them locate and see how new knowledge gained 
during class could be applied. For example:

"Learning more about the topic in a new and interesting way. Progressive. Build on what I have learnt in secondary school."

Students were asked specifically about their experiences during the CLS, the majority valued the opportunity to work with their peers. When asked to elaborate, students raised several attributes such as better retention of information, exchange of ideas, addressing knowledge gaps through their group mates and being more motivated to learn. Many students emphasized on that the arrangement of interactive learning and CLS provides enough opportunity to practice solving mathematics problem. Furthermore, smaller class size led to closer access to the teaching staff and as a result, students could clear remaining doubts almost immediately. Overall, the CLS seemed to have opened up more opportunities for students to articulate and grapple with the lesson content in a more intimate and conducive learning environment.

Although the outcomes were mainly positive, limitations were noted. Students were mixed in their responses when asked about the pace of the lesson, specifically the interactive seminars. Many felt that it was just nice, while others thought it was too slow. While this study does not seek to draw conclusions with regard to groups of students who are likely to benefit more from this integrated approach, it appears that interactive seminars may not be adequate in addressing the diverse learning needs of different students. This observation is congruous to Van Dijk and Jochem's (2002) study on interactive lectures. Another recurring point was the tendency for students to experience fatigue after the first hour of the interactive seminars. Short breaks could be given to address this.

\section{Conclusion}

Societal, economic and technological changes have redefined the role of a professional engineer. Being a professional engineer who is in the forefront of this evolution are not only expected to possess a good command of relevant knowledge but also the ability to be critical thinkers, effective in making informed decision, life-long learners, diversified social skills to work in different contexts and personals, and ability to be competent users of knowledge. To acquire these assortments of knowledge and skills as well as readiness to take on the demands of the today's society, education practices needs to take a radical change from conventional direct teaching approaches to a more constructivist framework whereby students are active participants in the learning process rather than a passive recipient of knowledge. However, simply putting students in a constructivist learning environment will not only be unhelpful to students, detrimental effects could happen as well if strategies are not in place to help learners acquire the necessary schema to be successful in this environment. In this paper, we have presented an integrated approach to teach engineering mathematics for first-year students in a post-secondary level institution. From the results of this study, following implications are suggested.

The first implication is that the instructors should pay close attention to the different emphases of instructional strategies when engaging learners in a constructivist approach to learning. Instructional guidance is needed to act as a substitution for the missing schemas that novices lack to process complex material. In the integrated approach, many forms of scaffolding opportunities and resources are provided. The lesson process does provide just-in-time information as it can include structured education activities and guidance through resources such as providing reading materials and practice questions that are relevant to the problem. Hard scaffolds such as computer or paper-based cognitive tools (e.g. worksheets) are provided once a task is assigned to the students (Saye \& Brush, 2002). These scaffolding materials can be designed based on various difficulty levels to support students' learning as they work on the task. In terms of soft scaffolds, which is dependent on the needs of the students during the time of instruction (Van Lier, 1996), the tutor actions in guiding students' learning processes and the formation of collaborative groups helps students to function in complex domains.

The second implication for designers would be to design authentic learning tasks for learners to apply the knowledge created in the course. Taking into consideration foundational mathematics modules are often offered 
to students from varying disciplines, designers need to design authentic tasks to have higher relevancy to their choice of disciplines or articulate how the tasks might be relevant to their context.

The third implication for instructors is to provide timely feedback to students during instructions and having a process in place to assure that students engage with it. Quality feedback needs to be targeted, timely and personalised. In addition, an effective communication method is needed to ensure that students engage with the feedback content.

Although the present study is not the first to suggest the use of interactive lecturing and small group learning environment in teaching mathematics, it has provided some valuable insights towards existing literature on considerations relating to implementing constructivist instructional approach in teaching engineering mathematics by describing one model of integrating interactive seminars and small group learning. Nevertheless, it needs to be stated that the conclusions of this study are still tentative as the focus concerned only one mathematics module. Future studies could examine the impact of such an approach on other fields such as the sciences and accounting. The role and the impact of the teaching staff also warrant further investigation. In the broader scheme of things, this study may compel math educators to reflect and innovate new and more effective approaches that enhance the student learning.

\section{References}

Artigue, M., \& Blomhøj, M. (2013). Conceptualizing inquiry-based education in mathematics. ZDM, 45(6), 797-810. http://dx.doi.org/10.1007/s11858-013-0506-6

Askew, M. (2001). Policy, practices and principles in teaching numeracy. In P. Grates (Ed.), Issues in mathematics teaching (pp. 105-119). London: Routledge Falmer.

Baxter, J. A., Woodward, J., \& Olson, D. (2001). Effects of reform-based mathematics instruction on low achievers in five third-grade classrooms. The Elementary School Journal, 101(5), 529-547. http://dx.doi.org/10.1086/499686

Borges, M. N., Goncalves, M. D. C. N. S., \& Cunha, F. M. (2003). Teaching and learning conceptions in Engineering Education: an innovative approach on Mathematics. European Journal of Engineering Education, 28(4), 523-534. http://dx.doi.org/10.1080/0304379032000101791

Bot, L., Gossiaux, P. B., Rauch, C. P., \& Tabiou, S. (2005). 'Learning by doing': a teaching method for active learning in scientific graduate education. European Journal of Engineering Education, 30(1), 105-119. http://dx.doi.org/10.1080/03043790512331313868

Cobb, P. (1988). The tension between theories of learning and instruction in mathematics education. Educational Psychologist, 23(2), 87-103. http://dx.doi.org/10.1207/s15326985ep2302_2

Cotton, T. (2001). Mathematics teaching in the real world. In P. Gates (Ed.), Issues in mathematics teaching (pp. 23-37). London and New York: Routledge Falmer.

Delaney, K. (2001). Teaching mathematics resourcefully. In P. Gates (Ed.), Issues in mathematics teaching (pp. 123-146). London and New York: Routledge Falmer.

Dolmans, D. H., \& Schmidt, H. G. (2006). What do we know about cognitive and motivational effects of small group tutorials in problem-based learning? Advances in Health Sciences Education, 11(4), 321-336. http://dx.doi.org/10.1007/s10459-006-9012-8

Dolmans, D. H., Wolfhagen, I. H., \& Ginns, P. (2010). Measuring approaches to learning in a problem based learning context. International Journal of Medical Education, 1, 55-60. http://dx.doi.org/10.5116/ijme.4c50.b666

Even, R., \& Kvatinsky, T. (2010). What mathematics do teachers with contrasting teaching approaches address in probability lessons? Educational Studies in Mathematics, 74(3), 207-222. http://dx.doi.org/10.1007/s10649-010-9234-9

Goodnough, K., \& Nolan, B. (2008). Engaging elementary teachers' pedagogical content knowledge: Adopting problem-based learning in the context of science teaching and learning. Canadian Journal of Science, Mathematics and Technology Education, 8(3), 197-216. http://dx.doi.org/10.1080/14926150802315130 
Integration of content instruction with constructivist-based strategies: An approach to engineering mathematics

Hart, K. M. (1980). Secondary school children's understanding of mathematics-Research monograph [A report of the mathematics component of the concepts in secondary mathematics and science programme]. Chelsea College, University of London.

Hiebert, J., Carpenter, T. P., Fennema, E., Fuson, K., Human, P., Murray, H., Olivier, A., \& Wearne, D. (1996). Problem solving as a basis for reform in curriculum and instruction: The case of mathematics. Educational Researcher, 25(4), 12-21. http://dx.doi.org/10.3102/0013189X025004012

Jaworski, B., \& Matthews, J. (2011). Developing teaching of mathematics to first year engineering students. Teaching Mathematics and its Applications, 30(4), 178-185. http://dx.doi.org/10.1093/teamat/hrr020

Kirschner, P. A., Sweller, J., \& Clark, R. E. (2006). Why minimal guidance during instruction does not work: An analysis of the failure of constructivist, discovery, problem-based, experiential, and inquiry-based teaching. Educational Psychologist, 41(2), 75-86. http://dx.doi.org/10.1207/s15326985ep4102_1

Kroesbergen, E. H., Van Luit, J. E., \& Maas, C. J. (2004). Effectiveness of explicit and constructivist mathematics instruction for low-achieving students in the Netherlands. The Elementary School Journal, 233-251. http://dx.doi.org/10.1086/499751

Md Kamaruddin, N., \& Wan Ahmad, W. (2007). A contextual approach, using problem-based, to teaching and learning differential equations in The Universiti Tun Hussein Malaysia. SEAMS 2007. Yogyakarta, Indonesia.

Md Kamaruddin, N., \& Wan Ahmad, W. M. R. (2007). A contextual approach to teaching and learning statistics in the Universiti Tun Hussein Malaysia. Paper presented in the International Conference on Research And Education on Mathematics (ICREM3). Kuala Lumpur, Malaysia.

National Council of Teachers of Mathematics. (1989). Curriculum and evaluation standards for school mathematics. Reston, VA: NCTM.

National Council of Teachers of Mathematics. (1991). Professional standards for teaching mathematics. Reston, VA: NCTM.

Nelson, C. E. (1996). Student diversity requires different approaches to college teaching, even in math and science. American Behavioral Scientist, 40(2), 165-175. http://dx.doi.org/10.1177/0002764296040002007

Poncy, B. C., McCallum, E., \& Schmitt, A. J. (2010). A comparison of behavioral and constructivist interventions for increasing math-fact fluency in a second-grade classroom. Psychology in the Schools, 47(9), 917-930. http://dx.doi.org/10.1002/pits.20514

Ronis, D. L. (2007). Problem-based learning for math \& science: integrating inquiry and the Internet. Arlington Heights: SkyLight Training and Publishing Company.

Savin-Baden, M. (2000). Problem-based learning in higher education: Untold stories. Buckingham, UK: Society for Research in Higher Education and Open University Press.

Sawyer, R. K. (2006). The Cambridge handbook of the learning sciences. New York: Cambridge University Press.

Saye, J. W., \& Brush, T. (2002). Scaffolding critical reasoning about history and social issues in multimedia-supported learning environments. Educational Technology Research and Development, 50(3), 77-96. http://dx.doi.org/10.1007/BF02505026

Shimazoe, J., \& Aldrich, H. (2010). Group work can be gratifying: Understanding and overcoming resistance to cooperative learning. College Teaching, 58(2), 52-57. http://dx.doi.org/10.1080/87567550903418594

Simpson, G., Hoyles, C., \& Noss, R. (2006). Exploring the mathematics of motion through construction and collaboration. Journal of Computer Assisted Learning, 22(2), 114-136. http://dx.doi.org/10.1111/j.1365-2729.2006.00164.x

Smith III, J. P. (1996). Efficacy and teaching mathematics by telling: A challenge for reform. Journal for Research in Mathematics Education, 27, 387-402. http://dx.doi.org/10.2307/749874

Sweller, J. (1988). Cognitive load during problem solving: Effects on learning. Cognitive Science, 12(2), 257-285. http://dx.doi.org/10.1207/s15516709 cog1202_4

Tynjälä, P. (1999). Towards expert knowledge? A comparison between a constructivist and a traditional learning environment in the university. International Journal of Educational Research, 31(5), 357-442. 
Choy, J. L. F., \& Yeo, W. L.

http://dx.doi.org/10.1016/S0883-0355(99)00012-9

Van Dijk, L. A., \& Jochems, W. (2002). Changing a traditional lecturing approach into an interactive approach: Effects of interrupting the monologue in lectures. International Journal of Engineering Education, 18(3), 275-284.

Van Lier, L. (1996). Interaction in the language curriculum: Awareness, autonomy and authenticity. New York: Longman.

Woods, D. R. (1996). Problem-based learning for large classes in chemical engineering. New directions for teaching and learning, 68, 91-99. http://dx.doi.org/10.1002/tt.37219966813

Yackel, E., Cobb, P., \& Wood, T. (1991). Small-group interactions as a source of learning opportunities in second-grade mathematics. Journal for Research in Mathematics Education, 22(5), 390-408. http://dx.doi.org/10.2307/749187 